\title{
SEASONAL WEATHER TRENDS IN RELATION TO FLUCTUATIONS OF THE JAN MAYEN GLACIERS SINCE I 920
}

\author{
By J. W. Sheard \\ (Department of Botany, Imperial College of Science and Technology, London, England)
}

\begin{abstract}
The meteorological records for Jan Mayen have been examined on a seasonal basis in order to obtain a clearer understanding of the fluctuations of the Beerenberg glaciers from 1920 to the present day. Summer and winter have been arbitrarily defined as including those months with mean monthly temperatures, at sea-level, above and below $0^{\circ} \mathrm{C}$., respectively. The results indicate that the retreat of Sørbreen prior to I940 was associated with high summer temperatures and high summer precipitation, and relatively low winter precipitation. A rapid rise in winter precipitation followed, which culminated about I950. The advance of Sørbreen since about 1954 is thought to have been caused by this rapid rise of precipitation and has also been associated with a slight drop in summer temperature, which is considered to be of secondary importance. The most recent trends of rising summer temperature since 1956 and falling winter precipitation since 1958 , if they continue, must lead to a renewed retreat of the glaciers. Studies on Sorbreen in the summer of $196_{3}$, which show that the recent advance has ceased, support this view.
\end{abstract}

RÉsumÉ. Variations saisonnières du temps en relation avec les fluctuations des glaciers de Jan Mayen depuis I920. Les observations météorologiques à Jan Mayen ont été étudiées sur des bases saisonnières en vue d'obtenir une compréhension plus claire des fluctuations des glaciers du Beerenberg depuis I920 jusqu'à nos jours. Hiver et été ont été arbitrairement définis comme contenant les mois où les températures moyennes mensuelles, au niveau de la mer, sont respectivement au-dessus et en-dessous de $0^{\circ} \mathrm{C}$. Les résultats montrent que le retrait du Sorbreen avant 1940 était associé à de hautes températures estivales et de fortes précipitations d'été, et à des précipitations d'hiver relativement faibles. Une rapide augmentation des précipitations d'hiver suivit qui culmina environ en 1950. L'avance du Sorbreen depuis environ 1954 semble être causée par cette rapide augmentation des précipitations, et aussi par la faible diminution des températures estivales considérée néanmoins de seconde importance. Les plus récentes tendances d'augmentation des températures estivales depuis 1956 et de diminution des précipitations hivernales depuis 1958, si elles se maintiennent, doivent conduire à un nouvel retrait des glaciers. Les études effectuées sur le Sørbreen en été I 963 , qui montrent que l'avance récente s'est arrètée, confirme ce point de vue.

Zusammenfassung. Fahreszeitlicher Wetterablauf in Beziehung zu Schwankungen der Gletscher auf Jan Mayen seit 1920. Die meteorologischen Aufzeichnungen für Jan Mayen wurden auf jahreszeitlicher Basis untersucht, um ein besseres Verständnis der Schwankungen der Beerenberg-Gletscher von 1920 bis heute zu gewinnen. Sommer und Winter wurden willkürlich als die Zeitabschnitte mit monatlichen Mitteltemperaturen über bzw. unter $0^{\circ} \mathrm{C}$ im Meeresniveau definiert. Die Ergebnisse zeigen, dass der Rückzug des Sørbreen vor $194{ }^{\circ}$ mit hohen Sommertemperaturen und hohem sommerlichem Niederschlag sowie relativ geringem winterlichen Niederschlag verknüpft war. Es folgte ein schneller Anstieg des winterlichen Niederschlags, der um 1950 seinen Höchstwert erreichte. Der Vorstoss des Sørbreen seit etwa 1954 wurde vermutlich durch diesen schnellen Anstieg des Niederschlages ausgelöst; er war auch von dem leichten Rückgang der Sommertemperatur begleitet, dem jedoch nur sekundäre Bedeutung beigemessen wird. Der jüngste Zug zu steigenden Sommertemperaturen seit 1956 und abnehmendem winterlichem Niederschlag seit 1958 muss-wenn er anhält-zu einem neuerlichen Rückgang der Gletscher führen. Diese Annahme wird durch Beobachtungen am Sorbreen im Sommer 1963, die ein Nachlassen des letzten Vorstosses zeigen, unterstützt.

\section{INTRODUCTION}

An advance of Sørbreen, the glacier which drains the southern ice field of Beerenberg, Jan Mayen, was first reported by Smith (unpublished), and Kinsman and Sheard (1963) showed this advance to be general, affecting most of the Beerenberg glaciers. The advance of the glaciers has been associated (Lamb and others, 1962) with a substantial increase in annual precipitation over the period $1922-6 \mathrm{I}$, for which meteorological data were available. This increase in precipitation, although accompanied latterly by a small drop in temperature, was thought to be the main cause of the advance. Further evidence of a general advance was found in 1963 but the terminal position of Sørbreen, the glacier for which most information is available, had remained almost unchanged since $196 \mathrm{r}$ and its snout had thinned considerably.

Although the recent increase in glacial activity has been correlated with an increase in annual precipitation, the possibility remains that the precipitation increment could be 
accounted for by an increase in summer precipitation alone. It is doubtful whether such an event could have led to the recent advance of the glaciers. In a similar manner the slight drop in mean annual temperature recorded might be due solely to a drop in summer temperature which could have had a very significant effect on the annual ablation. The present paper therefore sets out to explore the meteorological data in greater detail, in an attempt to elucidate these possibilities.

\section{Annual Precipitation and Temperature Data for Jan Mayen}

The trend of increasing precipitation shown by Lamb and others (1962, fig. I) has not been maintained during recent years, the smoothed precipitation values having dropped from $768 \mathrm{~mm}$. in 1958 to $717 \mathrm{~mm}$. in 1960 . It is too early to state whether this reversal represents a minor oscillation on a continuing trend of rising precipitation or the beginning of a longer period of decline. A decline in the precipitation at Jan Mayen might be expected in view of the recent decrease at other stations around the Norwegian Sea demonstrated by Lamb and others (1962).

A halt in the recent trend of rising temperature may also be indicated by the drop in smoothed temperature values from $-0.13^{\circ} \mathrm{C}$. in 1959 to $-0.17^{\circ} \mathrm{C}$. in 1960 , representing a return to the level of $195^{8}$. Mitchell (I96I) has already shown a general trend of falling surface temperatures from the 1940's to the 1950's in the Arctic generally, a trend which has not so far been demonstrated at Jan Mayen and certain other areas in the eastern Norwegian Sea. It would be unwise to predict, on the basis of the evidence, that the trend of falling temperature is now affecting the area around Jan Mayen.

Average monthly precipitation and temperature data are shown in Figure $\mathrm{I}$, based on records from I92 I (for temperature) and I 922 (for precipitation) up to I959. The seven months during which the average temperature is below $0^{\circ} \mathrm{C}$. account for rather less than 60 per cent of the total precipitation. Of particular importance to the regime of the glaciers are the two months, May and October, whose temperatures can be expected to fluctuate above and below $0^{\circ} \mathrm{C}$. Reference to the precipitation graph shows that May is the month of minimum precipitation, while October has the maximum. Small fluctuations in October temperatures might therefore be expected to produce relatively large changes in the regime of the glaciers.

\section{Seasonal Precipitation and Temperature Trends at Jan Mayen}

In an attempt to discover the seasonal distribution of precipitation and temperature at Jan Mayen, summer and winter have been defined as including those months in which the mean temperature rises above or falls below $0^{\circ} \mathrm{C}$., respectively, at sea-level. Sea-level is used as the datum, since meteorological records for Jan Mayen are taken at this level. These seasons should not be considered to represent the ablation and accumulation seasons on the glaciers, which they certainly do not. It is thought, however, that the trends of temperature and precipitation shown for the defined summer and winter seasons will reflect the trends of annual accumulation and ablation on the glaciers.

It is particularly unfortunate that October, the month of maximum precipitation, which has an average temperature of $0.5{ }^{\circ} \mathrm{C}$., should be assigned to the summer season for much of the period considered, because only in exceptional years could it be expected to fall in the ablation season. Precipitation and temperature trends for the months of May and October are, however, presented separately so that their contributions to the seasons may be assessed if desired. In the absence of upper air temperatures for Jan Mayen before the 1950's, it is impossible to establish an entirely satisfactory criterion for the separation of the accumulation and ablation seasons on the glaciers. 

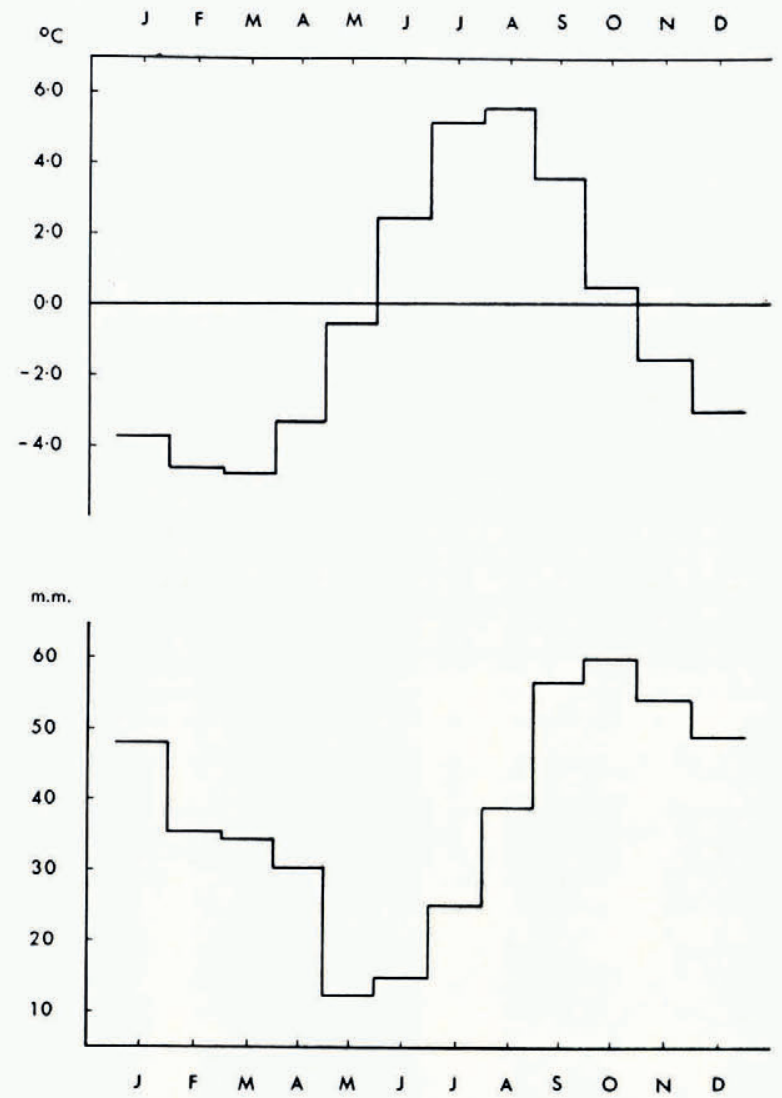

Fig. I. (a) Average monthly temperature (I92I-59); (b) average monthly precipitation (I922-59)

Trends have been obtained by applying a [4-] [4] smoothing function to the monthly and seasonal records, namely the operator

$$
\frac{1}{16}\left\{r_{n-3}+2 r_{n-2}+3{ }_{n-1}+4{ }_{n}+3 r_{n+1}+2 r_{n+2}+r_{n+3}\right\}
$$

where $Y_{n}$ stands for the value for the year $n$ and $Y_{n-1}$ for the value for the year before $n$ and so on. For reasons of clarity in presentation, annual records have not been given with the smoothed values in Figures 2-4. The scatter of these annual values about the smoothed graphs is of the same order as that given by Lamb and others (1962, fig. I) and Figure 5 of the present paper.

Figure 2 shows the smoothed curves for summer and winter precipitation, from which it is apparent that summer precipitation increased much more during the I930's than did winter precipitation, the trend culminating in an excess of summer over winter precipitation in the late I930's. After a period of relatively low precipitation in the early i940's, the trend was sharply reversed, culminating in a marked peak in winter precipitation in i 949 . The level of winter precipitation has since declined, with a minor peak in 1958 , and has been accompanied by a steady rise in summer precipitation. Records from recent years suggest that this rise in summer precipitation is tailing off. 


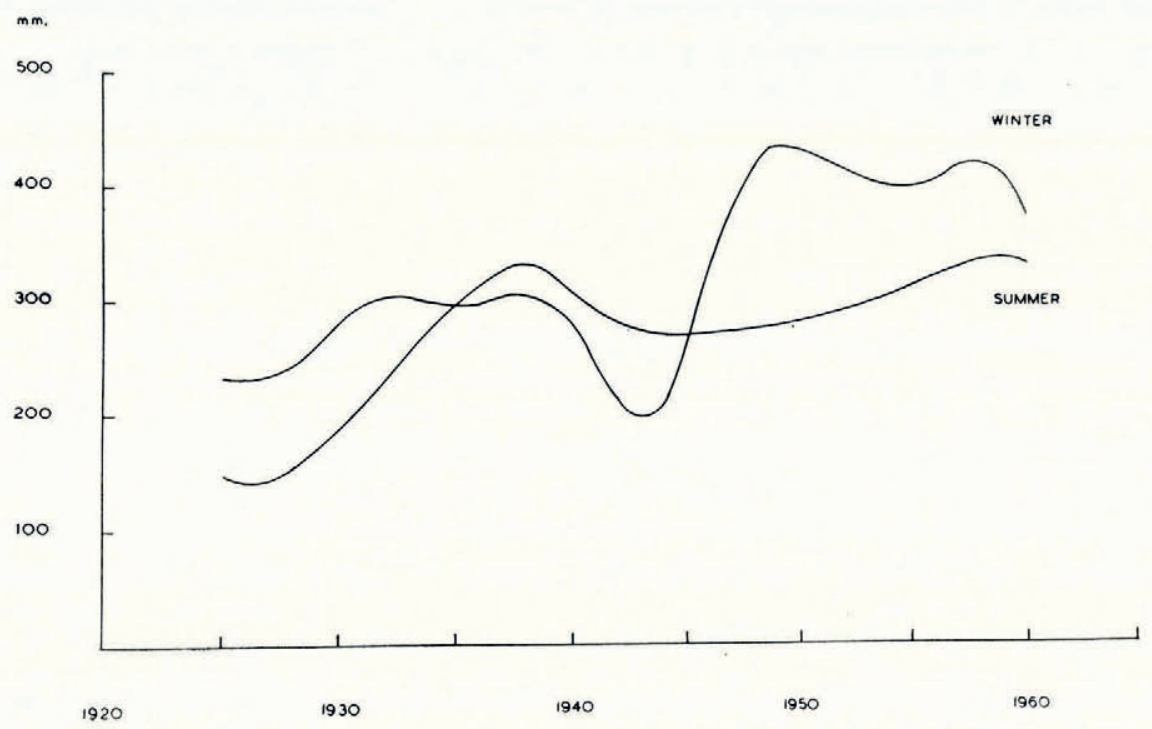

Fig. 2. Trends of winter and summer precipitation

Smoothed precipitation curves for the months of May and October (Fig. 3) both show a large but fluctuating increase. If the curves are considered in conjunction with the temperature trends for the same months (Fig. 4), it will be seen that between 1929 and 1948 the probability of October precipitation occurring in the summer increment increased, thus contributing to the levelling off of winter precipitation in the 1930's. A similar but less marked trend can be distinguished for May. Without these October and May increments there would not have

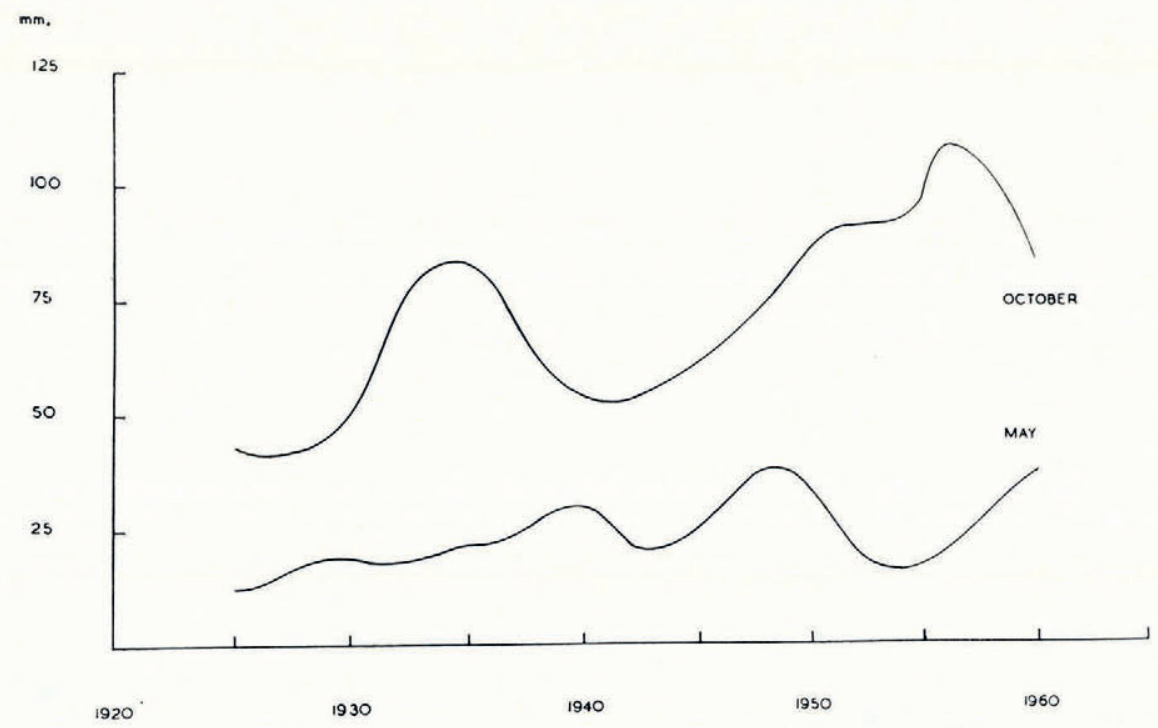

Fig. 3. Trends of May and October precipitation 
been an excess of summer precipitation in the late I930's. After I940, May and October temperatures have consistently remained below and above $0^{\circ} \mathrm{C}$., respectively.

Summer temperature and its consequent effect on summer ablation is also of primary importance to the regime of the glaciers. Figure 5 gives the trend of summer temperature (in ${ }^{\circ} \mathrm{C}$. months) since records commenced. A rise in temperature from 1928 and a distinct maximum during the late I930's can be correlated with rising May and October temperatures at this time. This maximum has been followed by a fluctuating decline in temperatures. The rise in summer temperature since 1956 has occurred in association with a small rise in October temperature.

\section{Discussion and Conclusions}

It has been suggested by Fitch and others (1962) that the advance of Sørbreen commenced about 1954 . In 1963 the snout was found to be roughly in the position recorded in 1961 . Prior to this period the glacier had been in rapid retreat since about 1920 .

The preceding analysis of meteorological data for Jan Mayen indicates that the retreat of the glaciers prior to the early I950's can be equated with the high summer temperatures and relatively low winter precipitation during the period prior to I940. The subsequent advance of Sørbreen might then be associated with the extremely rapid rise in winter precipitation that began in the early 1940's and culminated around 1950, together with the somewhat depressed summer temperatures of this period. A lag of $5^{-10} \mathrm{yr}$. between the change of weather trends and the response of the glacier snout is therefore indicated.

In addition to summer temperatures there is another factor which affects the amount of ablation on the glacier. This is summer precipitation. Precipitation on Jan Mayen is predominantly frontal, and Dibben ( 1965 ) has shown that heat transfer to the glacier is higher in periods of frontal weather than in non-frontal conditions. This is due to the relatively high latent and sensible heat transfers experienced in frontal conditions. The precipitation trends for summer are therefore of interest in that they indicate periods of high ablation apart from

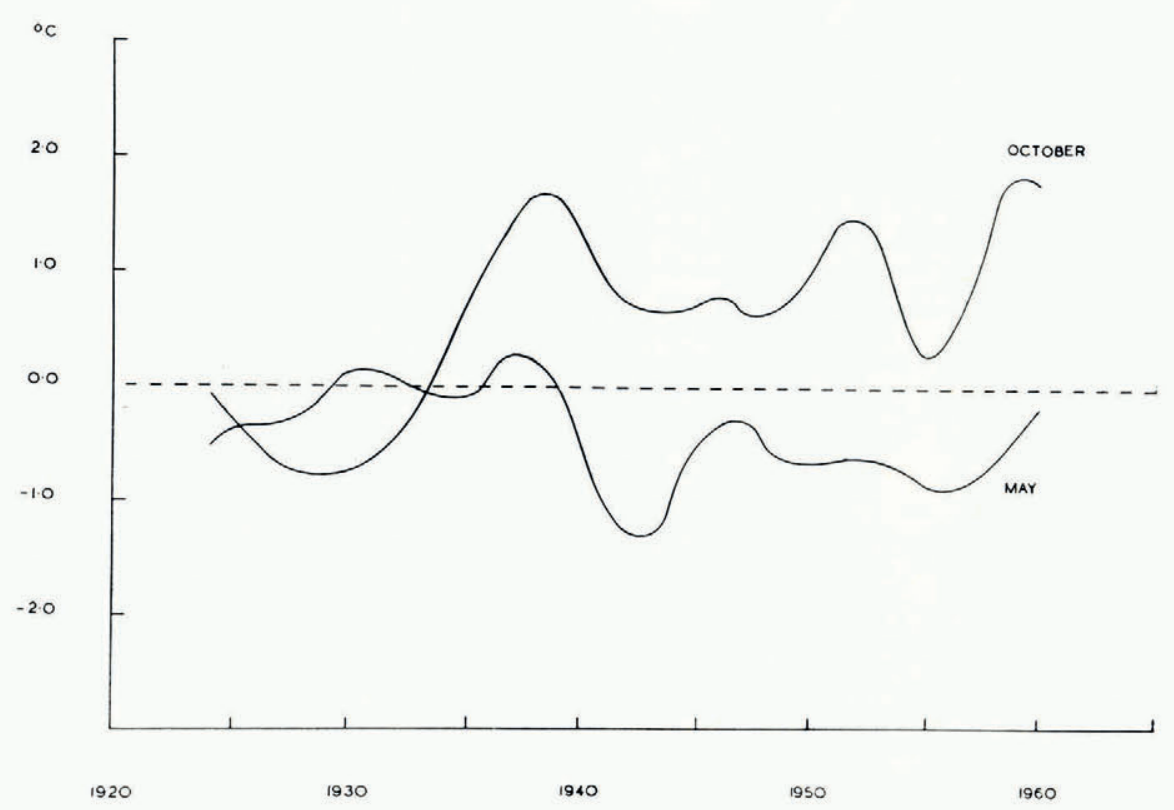

Fig. 4. Trends of May and October temperalure 
those due to high summer temperatures alone. For this reason Figure 2 shows that ablation would have been large in the late 1930's and late 1950's. A high level of ablation in the latter period may explain, in part, why the glacier has already ceased its advance in spite of the fact that a high level of winter precipitation was maintained during the period.

Fluctuations in May and October temperatures prior to 1940 played a significant part in determining the relative amounts of summer and winter precipitation. After this period the variations in winter precipitation and summer temperature largely reflect variations in the summer and winter months rather than changes in the spring and autumn weather patterns.

The most recent trends at Jan Mayen are of decreasing winter precipitation (since 1958) and of increasing summer temperature (since 1956 ). This, if the trends continue, must lead to an eventual decrease in glacial activity and finally to a retreat of the glaciers. The rapid rate of thinning at the snout of Sørbreen between 1961 and 1963 demonstrates a marked decline in activity, suggesting that the process may already be well developed.

It is interesting to note that Bray and Struick (1963) regard the advance of certain small glaciers in the Pacific north-west during the $195^{\circ}$ 's and 1960 's as being the result of an increase in snowfall during the late 1940 's and early I950's. They further report that the advance now seems to have slowed or stopped. It is perhaps remarkable that glaciers in such widely separated regions as Jan Mayen and the Pacific north-west should advance at the same time and from apparently the same causes. The rise in precipitation at Jan Mayen has been associated with increased activity of atmospheric and oceanic circulation in the North Atlantic, and the recent North American advance might point to a similar increase in activity in that sector of the Pacific. This, however, would be difficult to demonstrate because of the paucity of meteorological data before 1945 , when the change had probably already commenced.

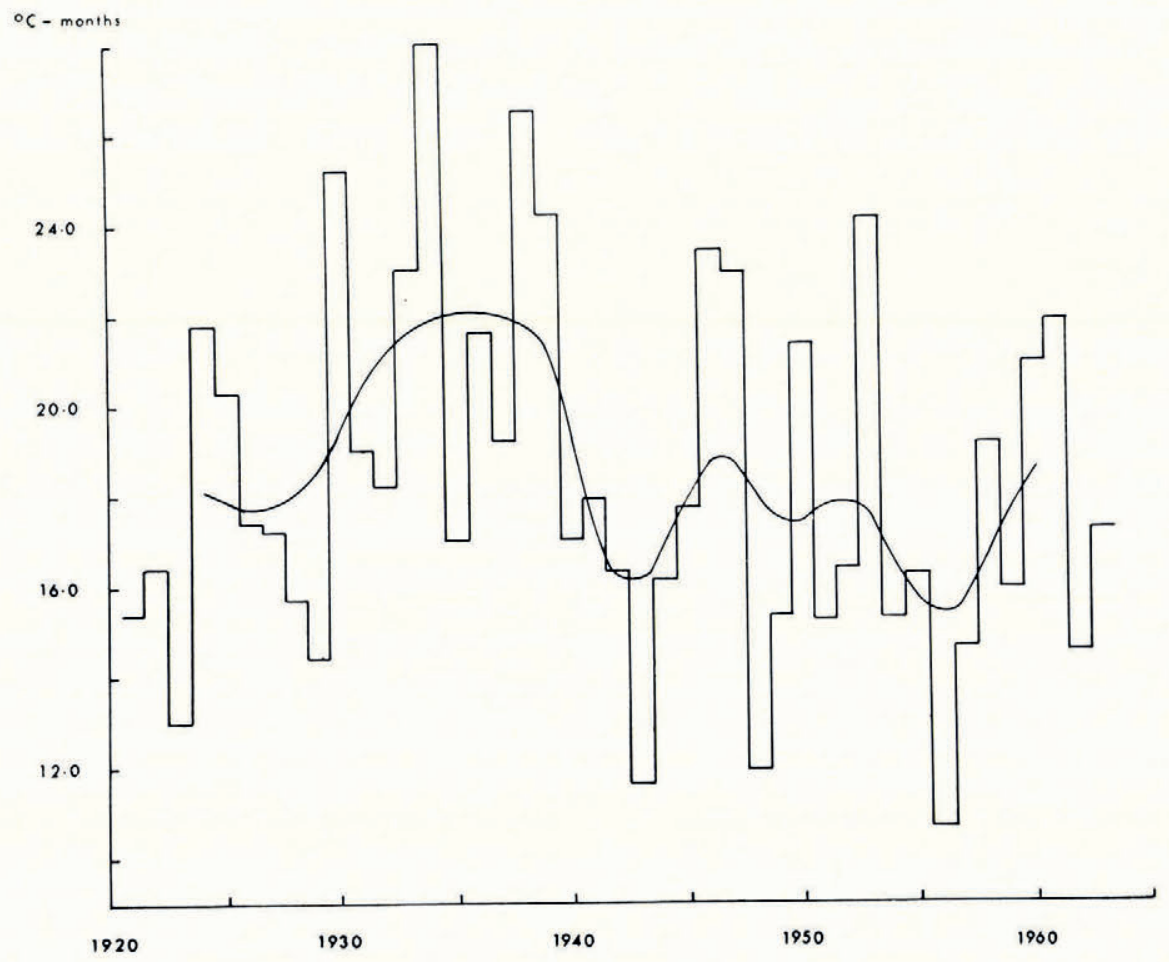

Fig. 5. Trend of annual summer temperature in degree months superimposed on annual totals 


\section{Acknowledgements}

The author wishes to thank P. C. Dibben, P. J. D. Guile, H. T. Lovenbury and P. F. Taylor for their valuable suggestions and for checking the manuscript of this paper. The 1963 Imperial College Beerenberg Expedition received considerable assistance from the Royal Society, the Mount Everest Foundation, North Atlantic Treaty Organization, the Royal Geographical Society and many private individuals, commercial firms and other organizations, to all of which sincere thanks are offered.

MS. received 9 October 1964 and in revised form 10 March 1965

\section{REFERENCES}

Bray, J. R., and Struick, G. J. 1963. Forest growth and glacial chronology in eastern British Columbia and their relation to recent climatic trends. Canadian Journal of Botany, Vol. 41, No. 8, p. 1245-71.

Dibben, P. C. 1965 . A heat-balance study on Sorbreen, Jan Mayen. Fournal of Glaciology, Vol. 5, No. 42, p. $793-803$.

Fitch, F. J., and others. 1962. Glacier re-advance on Jan Mayen, [by] F. J. Fitch, D. J. J. Kinsman, J. W. Sheard and D. Thomas. Union Géodésique et Géophysique Internationale. Association Internationale d'Hydrologie Scientifique. Commission des Neiges et Glaces. Colloque d'Obergurgl, $10-9-18-91962$, p. $201-11$.

Kinsman, D. J. J., and Sheard, J. W. r963. The glaciers of Jan Mayen. Journal of Glaciology, Vol. 4, No. 34, p. $439-48$.

Lamb, H. H., and others. 1962. A new advance of the Jan Mayen glaciers and a remarkable increase of precipitation, by H. H. Lamb, J. R. Probert-Jones and J. W. Sheard. Journal of Glaciology, Vol. 4, No. 33, p. 355-65.

Mitchell, J. M. 1961. Recent secular changes of global temperature. (In Solar variations, climatic change and related geophysical problems. Annals of the New York Academy of Sciences, Vol. 95, Art. 1, p. 235-50.)

Smith, P. Unpublished. Final report of the Imperial College section of the 1959 University of London Jan Mayen Expedition. [Presented 1960.] 